\title{
Energy expenditure of male farmers in dry and rainy seasons in Upper-Volta
}

\author{
BY THIERRY BRUN, FANNY BLEIBERG AND SAMUEL GOIHMAN \\ Unité de Recherches sur la Nutrition et l'Alimentation, U. 1. INSERM, Hôpital Bichat, \\ 170 Bd Ney, 75018 Paris, France
}

(Received 9 July 1980 - Accepted 20 July 1980)

1. Thirty Mossi male farmers from Upper-Volta were investigated, twenty-three in the dry season (March-April) and sixteen in the rainy season (July-August), eight of them being studied twice. A 48 h time-and-motion study was carried out and the daily energy expenditure was computed.

2. The mean height was $1.70 \mathrm{~m}$ and the mean weight $58.5 \mathrm{~kg}$. The average percentage of body fat calculated from skinfold thickness was 10 .

3. During the dry season the subjects could be classified as very moderately active with an energy output of 10.1 MJ $(2410 \mathrm{kcal}) / \mathrm{d}$. By contrast, with an energy expenditure of $14.4 \mathrm{MJ}(3460 \mathrm{kcal}) / \mathrm{d}$, they were considered as exceptionally active in July-August when performing the agricultural work.

4. In this study we measured the intensity of physical work in a society where human labour is still the main tool of production. The determination of seasonal variations in energy expenditure may be useful to assess the nutritional requirements in arid zones of West Africa.

One of the major features of the dry-land subsistence farming system of the Sahel region is its high dependence on rainfall and human labour. As precipitation is unpredictable and out of control, the only practical way by which farmers can increase staple food production is by dedicating more time and energy to extending cultivated areas and to increasing yields by better management. Most agricultural tasks are performed by hand and with rudimentary tools, therefore human energy devoted to production is, after rainfall, the major factor which determines the volume of cereal production in the subsistence farming sector.

During a time allocation study conducted by Ancey (1974), we observed that male farmers seldom worked more than 6-7 h daily even at the peak of activity in the rainy season. As a normal working day in industry represents $8 \mathrm{~h}$ of work, we wondered whether the shorter period of work observed in the Sahel region could not be explained on the basis of the high intensity of the work performed. In addition, several authors have reported changes in body-weight related to the pattern of farming activity (Fox, 1953; Hunter, 1967; Longhurst \& Payne, 1979). We, ourselves, observed mean seasonal weight losses of $2.8 \mathrm{~kg}$ for men and $0.7 \mathrm{~kg}$ for women between the post-harvest period (March-April) and the hungry season (July-August) in Upper-Volta (Brun et al. 1980).

As very few studies have been carried out on energy expenditure in arid zones, conclusive statements on possible energy deficit during the rainy season are difficult to make. Our lack of measurements of energy needs results in arbitrary interpretations of food consumption surveys (Longhurst \& Payne, 1979).

The present study was, therefore, undertaken as an attempt to assess the intensity of the tasks performed by the agriculturalists of a Sahel region and to measure their average daily energy expenditure, during both the dry and the rainy season. 


\section{MATERIALS AND METHODS}

\section{Ecological setting}

The Mossi plateau is flat, mainly between 250 and $500 \mathrm{~m}$ elevation above sea level, but interrupted occasionally by lateritic or granite hills seldom exceeding $600 \mathrm{~m}$ in height. Mean annual rainfall totals $700 \mathrm{~mm}$ in the northern part of our study area $\left(14^{\circ} \mathrm{N}\right)$ and $1000 \mathrm{~mm}$ in the southern part $\left(12^{\circ} \mathrm{N}\right)$. There are important variations in annual total precipitation, in the date of the first usable rain, and in the distribution of rain throughout the rainy season.

Frequently seeding has to be repeated if it does not rain within 7-10 d after sowing; thereafter well-spaced rainfall is necessary during the whole vegetative period but late rains or storm can be extremely damaging when millet (Pennisetum typhoïdes) or sorghum ears (Sorghum vulgare) have reached maturity.

The peasant economic life is characterized by two major seasons of activity with the onset of the rainy season in mid-May in the southern part of the study area and early June in the northern part.

Most of the agricultural activities are concentrated in the wet season as irrigated gardening is done in the dry season only in very limited areas not included in the villages studied.

The harvest is from October to December. At that period food resources are abundant and some cash is obtained from groundnuts (Arachis hypogaea), tobacco, sesame (Sesamum indicum) or tubers sold at the markets. However, granary and monetary resources are usually exhausted before June when the fields have to be cleared for the next crop.

Cultivated areas typically include three circles of cultivation around the village: the concession fields or 'champs de case'. They consist of a limited area around the mud huts which is constantly and regularly cultivated. They receive most of the manure from the small ruminants, horses and cows kept in the concessions as well as waste food.

Maize, red sorghum, beans (Vigna unguiculata), tubers, tobacco, okra, red sorrel and spices are cultivated in those fields.

However, this is seldom sufficient for most families and a semi-permanent circle of plots is cultivated in the vicinity with similar crops in addition to peas (Voandzeia subterranea) and groundnuts.

Additional fields are normally cultivated in the bush. These lands are left fallow for periods of 2-6 years, depending upon the family needs and the distance of the land from the village. Since the journey on foot between those plots and the concession is rather time-consuming some family members usually leave the village to settle in the bush during the period of cultivation, until the completion of harvest. Crops cultivated on these fields include millet, white or red sorghum, groundnuts, peas and beans.

Animal husbandry is practised throughout the year in the villages but the cattle are outside cultivated areas during the growth of cereals to avoid devastating the crops. Although there are often conflicts between the agriculturalists and the pastoralists, the Fulani herders often settle in the vicinity of cultivated areas in order to trade their milk and butter in the villages. They sometimes take charge of the Mossi cattle in exchange for cash or kind and they may be allowed to pasture the harvested plots in December.

The two villages Dablo and Nam-Ymi, where most of the observations and measurements were made, have been described in a previous article (Bleiberg et al. 1980). In addition to these villages, the rate of energy expenditure and the duration of activities was measured in the following villages: Doulougou and Wedbila respectively 27 miles and 17 miles south of Ouagadougou and Nagraogo, 82 miles north of Ouagadougou in the vicinity of Barsalogho. 
Table. 1. Physical characteristics of male subjects in Upper-Volta

\begin{tabular}{|c|c|}
\hline No. of men $\ldots$ & 30 \\
\hline \multicolumn{2}{|l|}{ Age (years) } \\
\hline Mean & $36 \cdot 6$ \\
\hline \multirow{2}{*}{\multicolumn{2}{|c|}{ Height (m) }} \\
\hline & \\
\hline Mean & 1.70 \\
\hline SE & 0.01 \\
\hline \multicolumn{2}{|l|}{ Wt (kg) } \\
\hline Mean & 58.5 \\
\hline SE & 1.38 \\
\hline \multicolumn{2}{|l|}{ Skinfold (mm) } \\
\hline \multicolumn{2}{|l|}{ Biceps } \\
\hline Mean & $3 \cdot 30$ \\
\hline SE & 0.09 \\
\hline \multicolumn{2}{|l|}{ Triceps } \\
\hline Mean & 4.9 \\
\hline $\mathbf{S E}$ & $0 \cdot 18$ \\
\hline \multicolumn{2}{|l|}{ Sub-scapular } \\
\hline Mean & $8 \cdot 6$ \\
\hline SE & 0.3 \\
\hline \multicolumn{2}{|l|}{ Supra-iliac } \\
\hline Mean & $6 \cdot 2$ \\
\hline & $0 \cdot 37$ \\
\hline \multicolumn{2}{|l|}{ Fat $(\%)$} \\
\hline Mean & $10 \cdot 3$ \\
\hline $\mathbf{S E}$ & 0.39 \\
\hline
\end{tabular}

\section{Subjects}

A total of thirty men participated in the study, twenty-three of them being investigated during the dry season and sixteen during the rainy season, eight of them being included in both surveys. All the subjects were peasants, although some of them dedicated part of their time to handicraft or marketing. They can be considered as representative of the Mossi farmers based on factors presented previously.

\section{Methods}

Essentially, the same methods reported in a previous paper (Bleiberg $e t$ al. 1980) have been used in this study: each man was followed by an observer throughout the waking day for $48 \mathrm{~h}$ and the time spent in each activity was accurately recorded. The metabolic rate of the main activities was measured using a Kofranyi-Michaelis respirometer and the expired air was analysed by means of a Servomex oxygen analyser (AO 240) regularly calibrated with a gas mixture: $\mathrm{O}_{2}$-carbon dioxide-nitrogen (12:5:83, by vol). The energy expenditure was computed from the equation given by Durnin \& Passmore (1967). As we could not measure the metabolic rate of all the activities, we used either estimated values or values obtained from the literature in order to calculate the daily energy expenditure. The energy expenditure during sleep was assessed by a $15 \%$ reduction of the metabolic rate of subjects lying inactive.

The anthropometric measurements were made according to the methods presented previously (Bleiberg et al. 1980).

Results are given as mean values \pm 1 standard error of the mean. Comparisons between the durations of categories of activity during the dry and rainy seasons were made using the distribution free Mann \& Whitney $U$ test. 
Table 2. Energy expenditure at rest and at work in Upper-Volta (Mean values with their standard errors)

\begin{tabular}{|c|c|c|c|c|c|}
\hline \multirow[b]{3}{*}{ Activities } & \multirow{3}{*}{$\begin{array}{c}\text { No. of } \\
\text { subjects }\end{array}$} & \multicolumn{4}{|c|}{ Energy cost* } \\
\hline & & \multicolumn{2}{|c|}{$\mathrm{kJ} / \mathrm{min}$} & \multicolumn{2}{|c|}{$\mathrm{kcal} / \mathrm{min}$} \\
\hline & & Mean & SE & Mean & SE \\
\hline Lying & 31 & 5.81 & $0 \cdot 151$ & 1.39 & 0.036 \\
\hline Sitting & 33 & $5 \cdot 77$ & $0 \cdot 180$ & $1 \cdot 38$ & 0.043 \\
\hline Standing & 29 & $6 \cdot 02$ & 0.188 & 1.44 & 0.045 \\
\hline Walking & 25 & $15 \cdot 0$ & 0.51 & 3.6 & 0.12 \\
\hline Walking slowly & 4 & $12 \cdot 3$ & 0.50 & $2 \cdot 9$ & 0.12 \\
\hline Walking fast & 2 & $17 \cdot 6$ & 1.97 & $4 \cdot 2$ & 0.47 \\
\hline Cycling & 12 & $18 \cdot 4$ & $1 \cdot 42$ & $4 \cdot 4$ & 0.34 \\
\hline Sowing & 5 & 16.4 & $1 \cdot 55$ & 3.9 & 0.37 \\
\hline Thinning out and replanting & 8 & $15 \cdot 8$ & $1 \cdot 21$ & 3.8 & 0.29 \\
\hline Hoeing & 11 & $21 \cdot 3$ & 0.92 & $5 \cdot 1$ & 0.22 \\
\hline Land clearing & 2 & $29 \cdot 0$ & 1.09 & 6.9 & 0.26 \\
\hline \multicolumn{6}{|l|}{ Sorghum harvest: standing, cutting the ears with a } \\
\hline knife or by hand & 6 & $10 \cdot 0$ & 0.46 & $2 \cdot 4$ & $0 \cdot 11$ \\
\hline Bent forward, uprooting sweet potatoes with a hoe & 5 & $16 \cdot 3$ & $1 \cdot 59$ & 3.9 & 0.38 \\
\hline \multicolumn{6}{|l|}{ Plucking leaves and stems from sweet potato plants, } \\
\hline standing & 1 & $28 \cdot 5$ & - & $6 \cdot 8$ & - \\
\hline Kneeling and sorting sweet potatoes & 1 & 7.4 & - & 1.8 & - \\
\hline Cutting straw with a sickle, bent forward & 3 & 23.4 & 2.67 & $5 \cdot 6$ & 0.64 \\
\hline Walking with a sheaf of straw on his head $(11.5 \mathrm{~kg})$ & 1 & $14 \cdot 2$ & - & $3 \cdot 4$ & - \\
\hline \multicolumn{6}{|l|}{ Pulling and breaking into pieces branches from dead } \\
\hline trees, walking and bending forward & 2 & $15 \cdot 9$ & 0.08 & $3 \cdot 8$ & 0.02 \\
\hline Cutting wood with a machete, standing & 1 & $19 \cdot 2$ & - & $4 \cdot 6$ & - \\
\hline Unloading a cart of branches & 2 & $15 \cdot 0$ & 0.50 & $3 \cdot 6$ & 0.12 \\
\hline Vine weaving & 2 & $9 \cdot 8$ & 0.54 & $2 \cdot 4$ & $0 \cdot 13$ \\
\hline Hand weaving sitting on the ground & 2 & 10.9 & $1 \cdot 30$ & $2 \cdot 6$ & 0.31 \\
\hline Hand sewing & 1 & $7 \cdot 5$ & - & $1 \cdot 8$ & - \\
\hline Sewing with treadle sewing machine & 3 & $10 \cdot 0$ & 0.29 & $2 \cdot 4$ & 0.07 \\
\hline Clay kneading & 1 & $12 \cdot 5$ & - & $3 \cdot 0$ & - \\
\hline Sawing a calabash by hand, bending forward & 1 & $13 \cdot 0$ & - & $3 \cdot 1$ & - \\
\hline Making mud bricks, squatting & 3 & $13 \cdot 8$ & 0.59 & $3 \cdot 3$ & $0 \cdot 14$ \\
\hline Standing making a mud wall & 1 & $7 \cdot 1$ & - & 1.7 & - \\
\hline Digging the earth with a pick-axe to make mud & 2 & $26 \cdot 6$ & $4 \cdot 18$ & $6 \cdot 4$ & $1 \cdot 00$ \\
\hline Shovelling the mud & 2 & $20 \cdot 5$ & $4 \cdot 39$ & 4.9 & 1.05 \\
\hline Copying verses of the Koran, sitting & 1 & $5 \cdot 1$ & - & $1 \cdot 2$ & - \\
\hline
\end{tabular}

* Energy cost corresponding to a standard weight of $60 \mathrm{~kg}$.

\section{RESULTS}

\section{Anthropometric measurements}

The men involved in this study were aged 20-40 years (Table 1). They were on the average 6 years older than the women studied in the same villages. The mean weight-for-height was $87 \%$ of the Interdepartmental Committee on Nutrition for National Development Standard (Inter-departmental Committee on Nutrition for National Development, 1963). Their height was $0.15 \mathrm{~m}$ higher and their weight, $10.8 \mathrm{~kg}$ heavier than that of women from the corresponding villages. Body fat, calculated from skinfold thickness, was approximately $10 \%$, that is half the value found for female farmers. As for women, the thickness of the skinfold over the triceps was below $60 \%$ of the standard given by Jelliffe (1969).

\section{Energy cost of the main activities}

The results for the energy cost of the various activities are shown in Table 2. As we had found for female subjects, the difference between the average energy expenditure for lying, 
Table 3. Daily mean duration (min) of various types of activities of male farmers in dry and rainy seasons in Upper-Volta

(Mean duration)

\begin{tabular}{|c|c|c|c|}
\hline Type of activities & $\begin{array}{c}\begin{array}{c}\text { Dry } \\
\text { season }\end{array} \\
\end{array}$ & $\begin{array}{c}\text { Statistical } \\
\text { significance } \\
\text { of } \\
\text { difference } \\
\text { between } \\
\text { means: } P<\end{array}$ & $\begin{array}{l}\text { Rainy } \\
\text { season }\end{array}$ \\
\hline $\begin{array}{l}\text { Resting activities } \\
\text { Sleeping } \\
\text { Lying } \\
\text { Sitting } \\
\text { Standing }\end{array}$ & $\begin{array}{r}998.0 \\
582.0 \\
44.0 \\
312.0 \\
60.0\end{array}$ & 0.001 & $\begin{array}{r}833 \cdot 0 \\
518 \cdot 0 \\
25 \cdot 0 \\
245 \cdot 0 \\
45 \cdot 0\end{array}$ \\
\hline $\begin{array}{l}\text { Other daily life activities } \\
\text { Walking } \\
\text { Riding a donkey } \\
\text { Cycling } \\
\text { Washing } \\
\text { Praying } \\
\text { Writing } \\
\text { Playing cards } \\
\text { Visiting friends, health centre and social activities }\end{array}$ & $\begin{array}{r}55 \cdot 0 \\
5 \cdot 0 \\
18 \cdot 0 \\
6 \cdot 0 \\
6 \cdot 0 \\
1 \cdot 0 \\
52 \cdot 0\end{array}$ & 0.05 & $\begin{array}{r}46.0 \\
1.0 \\
5.0 \\
6.0 \\
7.0 \\
- \\
- \\
4.0\end{array}$ \\
\hline $\begin{array}{l}\text { At the market } \\
\text { Walking to and from } \\
\text { Cycling to and from } \\
\text { Purchasing, walking and loitering } \\
\text { Selling }\end{array}$ & $\begin{array}{r}151.0 \\
12.0 \\
12.0 \\
103 \cdot 0 \\
24 \cdot 0\end{array}$ & NS & $\begin{array}{r}33.0 \\
6.0 \\
1.0 \\
26.0 \\
-\end{array}$ \\
\hline Housework & $22 \cdot 0$ & NS & 9.0 \\
\hline Handicrafts at home & $71 \cdot 0$ & 0.05 & $24 \cdot 0$ \\
\hline $\begin{array}{l}\text { Farming } \\
\text { Walking to and from the fields } \\
\text { Cycling to and from the fields } \\
\text { Threshing millet } \\
\text { Collecting manure } \\
\text { Tending tobacco } \\
\text { Tree planting } \\
\text { Hoeing } \\
\text { Thinning out and replanting } \\
\text { Clearing the bush } \\
\text { Clearing shrubs from fields } \\
\text { Sowing } \\
\text { Burning weeds before planting } \\
\text { Irrigating tobacco plants }\end{array}$ & $\begin{array}{r}19.5 \\
3.0 \\
5 \cdot 0 \\
5 \cdot 0 \\
2 \cdot 0 \\
4 \cdot 0 \\
0.5 \\
= \\
= \\
= \\
= \\
=\end{array}$ & 0.001 & $\begin{array}{r}438.0 \\
32 \cdot 0 \\
3 \cdot 0 \\
- \\
= \\
= \\
284 \cdot 0 \\
104 \cdot 0 \\
4 \cdot 0 \\
6.0 \\
3 \cdot 0 \\
1.0 \\
1.0\end{array}$ \\
\hline Hunting & $24 \cdot 0$ & & - \\
\hline Animal husbandry & $6 \cdot 0$ & 0.05 & $25 \cdot 0$ \\
\hline Teaching religion or making clothes & $5 \cdot 0$ & NS & $9 \cdot 0$ \\
\hline
\end{tabular}

NS, not significant.

sitting and standing was not significant. Christensen (1953) presents a grading system for men performing industrial tasks. By this system, among the measured activities, only land clearing would be classified as heavy work; hoeing, plucking leaves and stems from sweet potato (Impomea batatas) plants, cutting straw with a sickle and digging the earth with a pick-axe to make mud are activities which could be classified as moderate and the others fall in the 'light activity' category. 
Pattern of activities in dry and rainy seasons

The definition and classification of the various activities are basically the same as those used for women (Bleiberg et al. 1980). The duration of each activity reported in Table 3 did not usually include the period of rest within the activity. Rest periods were therefore separated and included under the appropriate headings: sitting or standing inactive. An exception to this rule was made for visiting friends, social activity and visiting the market.

The occupations of the farmers during the two seasons were very different. As they had almost no agricultural work during the dry season, they spent daily on the average $1 \mathrm{~h}$ more sleeping, $1 \mathrm{~h}$ more sitting inactive and $1 \mathrm{~h}$ more visiting friends. For this last activity as well as resting activities, the difference between the two seasons was statistically significant $(P<0.05$ and $P<0.001$ respectively $)$.

In the dry season men wandered around the market more than $1.5 \mathrm{~h}$ for miscellaneous purchases and on the average $0.3 \mathrm{~h}$ selling their farm products (millet, sorghum, groundnuts, tobacco, etc.).

By contrast, during the rainy season only $0.5 \mathrm{~h}$ was spent at the market, mostly loitering and purchasing miscellaneous articles needed at home for maintenance, repairs or entertainment, but the difference between the two seasons was not significant.

Most farmers spent $1 \mathrm{~h}$ or more daily in handicraft activities during the dry season, making straw mats and rubber sandals from old tyres, weaving baskets or plaiting vines into ropes, hammering pieces of iron into agricultural tools or repairing the mud walls of their houses.

During the period of hard physical work the duration of handicraft activities was reduced to $0.3 \mathrm{~h}$ daily and the difference between seasons was statistically significant $(P<0.05)$. Most of the time was then dedicated to farming - that is, hoeing, weeding and transplanting sorghum or millet shoots to the parts of the fields where germination had failed or young plants had dried.

Almost no time was spent by men in tending children, washing and dressing during the rainy season whereas almost $0 \cdot 3 \mathrm{~h}$ are devoted daily to those activities during the dry season. However, the fact that only a few minutes are indicated under the heading 'tending children' might be misleading. Part of the time spent by the adults with their children is indicated under sitting or standing, as it involved little or no physical activity.

After the harvest, the cattle could wander freely to graze on the stalks of millet or sorghum, but when the rains came they had to be locked up and fed. This required approximately $0.4 \mathrm{~h}$ daily - significantly more than in the dry season $(P<0.05)$.

The time dedicated to housework was very short in both seasons.

\section{Daily energy output}

During the dry season the energy expenditure was approximately $10 \mathrm{MJ}(2410 \mathrm{kcal}) / \mathrm{d}$ and it increases by $4 \mathrm{MJ}(1000 \mathrm{kcal}) / \mathrm{d}$ at the peak of the rainy season (Table 4). According to the grading system given by FAO/WHO (1973), in the dry season the male farmers are classified as very moderately active, with a mean energy cost of $0.17 \mathrm{MJ} / \mathrm{kg}$ body-weight $(40.2 \mathrm{kcal})$, and in the rainy season they belong to the category 'exceptionally active' $(0.24$ MJ or $57.7 \mathrm{kcal} / \mathrm{kg}$ body-weight).

\section{DISCUSSION}

The energy expenditure whilst lying could not be measured under basal conditions, which explains that the values found for male farmers are higher than those given by Durnin \& Passmore (1967) for Scottish males of the same weight and the same percentage of fat just before rising.

The metabolic rate for sitting and standing falls within the normal range of values 
Table 4. Daily energy expenditure of male farmers in dry and rainy seasons in Upper-Volta

(Mean values $\dagger$ with their standard errors)

\begin{tabular}{ccccccc}
\hline & \multirow{2}{*}{$\begin{array}{c}\text { No. of } \\
\text { subjects }\end{array}$} & \multicolumn{2}{c}{ MJ } & & \multicolumn{2}{c}{ kcal } \\
\cline { 4 - 5 } \cline { 5 - 6 } & Mean & SE & & Mean & SE \\
\hline Dry season & 23 & $10 \cdot 1$ & $0 \cdot 25$ & & 2410 & $61^{* * *}$ \\
Rainy season & 16 & $14 \cdot 4$ & $0 \cdot 41$ & & 3460 & 99 \\
\hline
\end{tabular}

*** $P<0.001$

+ Corresponding to a standard weight of $60 \mathrm{~kg}$.

reported by the authors quoted previously, but, on average, the Africans expend less energy whilst standing than the Europeans.

The fact that no significant difference could be observed between the energy cost of lying, sitting and standing has already been reported by other authors in Jamaica and in Africa. Ashworth (1968) found that when male and female Jamaican subjects were changing from a lying to a sitting position, the increase in energy expenditure was much lower than the value indicated for Europeans. Dieng et al. (1980) also obtained the same result when comparing the energy cost of lying and standing between West African and European male subjects. In a group of male Nigerians, Phillips (1954) measured an average energy expenditure of $6.3 \mathrm{~kJ}(1.5 \mathrm{kcal})$ for both sitting and standing. This value is in close agreement with our own results.

The levels of metabolic rate determined during several types of activity such as walking, hoeing and head panning published by Phillips (1954) and those presented in this study are very similar.

Very few studies on the seasonal variation in the energy expenditure in arid zones are available. Fox (1953) reported an energy output of $14.4 \mathrm{MJ}$ (3438 kcal) for male farmers during the wet season and Dema (1967) estimated an average value of $13 \mathrm{MJ}(3120 \mathrm{kcal})$ from a time and motion study.

In a previous report (Bleiberg et al. 1980), we mentioned the numerous sources of errors which are inherent in these types of studies. Fortunately, we were able to compare our short-term record of daily activity with the other survey conducted by Ancey (1974) in Upper-Volta for one complete year on a much larger sample of the population (Table 5). The levels of energy expenditure calculated from both studies are in close agreement.

As we observed that part of the daily activities was performed by both male (the present study) and female farmers (Bleiberg et al. 1980), it seemed interesting to us to compare these two groups. In order to consider the duration of the main activities which are common to male and female farmers in each season for the same villages, we computed the results obtained for the female subjects in Dablo and Nam-Ymi (Bleiberg et al. 1980) and also in Doulougou, Wedbila and Nagraogo (Bleiberg, unpublished results). The results are shown in Table 6.

In the rainy season when hard physical work is performed, men and women spend the same amount of time in resting activities such as sleeping, lying, sitting or standing inactive. By contrast during the dry season, the men sleep $0.7 \mathrm{~h}$ longer $(P<0.001)$, they remain lying $0.2 \mathrm{~h}$ more, but above all they rest daily sitting inactive almost $2 \mathrm{~h}$ more than their spouses $(P<0.01)$. The time spent daily walking for other purposes than the market is similar for both sexes and both seasons.

When there is no agricultural work men can devote almost $1 \mathrm{~h}$ daily to social activities: visiting friends, attending marriages or religious feasts; but women, neither during this season nor the rainy season, can spend even $\mathbf{0 . 2} \mathrm{h}$ daily socializing. Whereas for female 
Table 5. Mean daily energy expenditure of male farmers in Upper-Volta computed from recordings of activity during 1973 (Ancey, 1974)

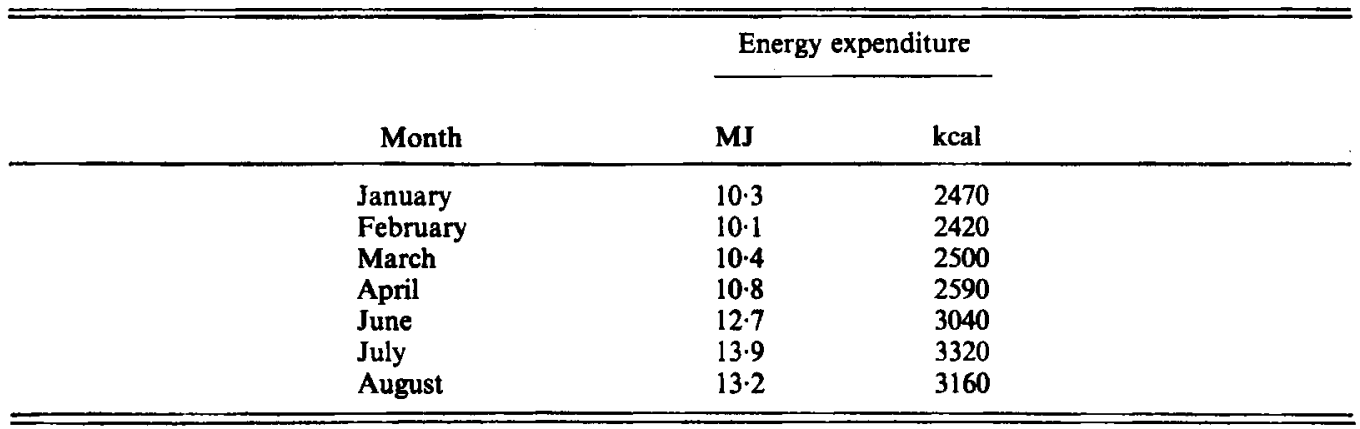

Table 6. Comparison of the duration (min) of main common activities of male and female farmers $\dagger$ in dry and rainy seasons

\begin{tabular}{|c|c|c|}
\hline \multirow[b]{2}{*}{ Type of activities } & \multicolumn{2}{|c|}{ Mean duration } \\
\hline & Dry season & Rainy season \\
\hline Sleeping & $\begin{array}{l}\text { o } 582 \cdot 0^{* * * *} \\
\text { o } 544 \cdot 0\end{array}$ & $\begin{array}{ll}\delta & 518 \cdot 0^{\mathrm{NS}} \\
\text { o } & 523 \cdot 0\end{array}$ \\
\hline Lying & $\begin{array}{ll}\text { o } & 44 \cdot 0^{\mathrm{NS}} \\
\text { o } & 30 \cdot 0\end{array}$ & $\begin{array}{ll}\text { o } & 25 \cdot 0^{\mathrm{NS}} \\
\text { q } & 28 \cdot 0\end{array}$ \\
\hline Sitting & $\begin{array}{ll}\text { o } & 312 \cdot 0^{* *} \\
\text { ㅇ } & 197 \cdot 0\end{array}$ & $\begin{array}{ll}\text { ১ } 246 \cdot 0^{\mathrm{NS}} \\
\text { ९ } 207 \cdot 0\end{array}$ \\
\hline Standing & $\begin{array}{ll}\text { o } & 60 \cdot 0^{\mathrm{NS}} \\
\text { q } & 45 \cdot 0\end{array}$ & $\begin{array}{ll}\text { o } & 45 \cdot 0^{\mathrm{NS}} \\
\text { ㅇ } & 65 \cdot 0\end{array}$ \\
\hline Total resting activities & $\begin{array}{l}\text { of } 996 \cdot 0^{* * *} \\
\text { ㅇ } 836.0\end{array}$ & $\begin{array}{l}\text { o } 833 \cdot 0^{\mathrm{NS}} \\
\text { o } 803 \cdot 0\end{array}$ \\
\hline Walking & \begin{tabular}{ll}
\multirow{\jmath}{*}{} & $55 \cdot 0^{\mathrm{NS}}$ \\
$q$ & $50 \cdot 0$
\end{tabular} & $\begin{array}{ll}\overbrace{}^{*} & 46 \cdot 0^{\mathrm{NS}} \\
\text { ᄋ } & 34 \cdot 0\end{array}$ \\
\hline Social activities & $\begin{array}{cc}\text { o } & 52 \cdot 0^{*} \\
q & 8.0\end{array}$ & - \\
\hline Market & $\begin{array}{lc}\text { o } & 151 \cdot 0^{\mathrm{NS}} \\
\text { o } & 46.0\end{array}$ & $\begin{array}{ll}\text { o } & 33 \cdot 0^{\mathrm{NS}} \\
\text { o } & 47.0\end{array}$ \\
\hline Handicraft & $\begin{array}{lc}\text { o } & 71 \cdot 0^{\mathrm{NS}} \\
\text { q } & 116.0\end{array}$ & - \\
\hline Agricultural activities & - & $\begin{array}{l}\text { * } 438 \cdot 0^{* * * *} \\
\text { \& } 222 \cdot 0\end{array}$ \\
\hline
\end{tabular}

NS, not significant.

* $P<0.05, * * P<0.01, * * * P<0.001$.

$\dagger$ Twenty-three and nineteen female farmers were investigated in dry and rainy seasons respectively.

farmers the period of time spent at the market does not vary much with the season, male farmers spend $2 \mathrm{~h} / \mathrm{d}$ more in the dry season than in the rainy season $(0.5 \mathrm{~h} / \mathrm{d})$; that is, three times as much as women when men have no work and the same time spent by women when men must work in their fields. Women must sell their products (doughnuts, groundnut paste, fermented locust bean (Parkia biglobosa), handicrafts) the year round in order to purchase spices, small amounts of dried fish or other food products. Male farmers, by contrast, sell part of their production of staple food (sorghum, millet, tubers or groundnuts) only during a few months after harvest. At the time of the survey this required approximately $0.3 \mathrm{~h}$ 
daily and the rest of the time spent at the market consisted of loitering, chatting with friends and purchasing miscellaneous products for home consumption or handicrafts.

On the whole, men have much more leisure time than women during the dry season since female farmers devote several hours daily to housework. The male subjects also spend less time $(1.2 \mathrm{~h} v .1 .9 \mathrm{~h})$ than women in handicraft during the dry season but this difference is not statistically significant.

The major difference between male and female farmers lies in the duration of hard physical work during the rainy season $(P<0.001)$. Women, however, are not exempted from long hours $(3.7 \mathrm{~h} / \mathrm{d})$ of strenuous activities.

The difference in energy output found in the male group between dry and rainy seasons was twice as large as that computed for the female farmers (Bleiberg $e t$ al. 1980). This finding is still true if we consider the female subjects living in the five investigated villages since the pattern of activities is not different between Nam-Ymi and Dablo on one hand and Doulougou, Wedbila and Nagraogo on the other.

While both men and women expend high or exceptionally high levels of energy expenditure at the peak of agricultural activities, men are able to rest comparatively more than women during the dry season. These observations confirm on one hand that subsistence agriculture in the arid zone requires large amounts of physical work and on the other, that female Mossi agriculturalists are apparently more overworked than men. Further studies could be initiated in order to test whether maximum work capacity is attained in the rainy season and whether the long resting period of men during the dry season is indispensable to reconstitute their physical fitness after a period of strenuous work. Although we do not have firm evidence of this, our belief is that both hypotheses are very likely to be true.

The authors gratefully acknowledge the help received from Emile Gouba chief of the Nutrition Unit (Ministry of Health) in Ouagadougou, and Robert Poivre for his skilled technical assistance.

This investigation was supported by several grants made to Thierry Brun from the Délégation Générale à la Recherche Scientifique et Technique (Paris) (nos. 75.7.1279; 76.7.0847; 78.7.0081).

\section{REFERENCES}

Ancey, G. (1974). Facteurs et Systèmes de Production dans la Société Mossi d'Aujourd hui, Migration-Travail; Terre et Capital. ORSTOM: Centre de Ouagadougou.

Ashworth, A. (1968). Br. J. Nutr. 22, 341.

Bleiberg, F., Brun, T., Goihman, S. \& Gouba, E. (1980). Br. J. Nutr. 43, 71.

Brun, T., Bleiberg, F., Ancey, G., Bonny, S. (1980). Environ. Afric., Dakar. 73, 15.

Christensen, E. H. (1953). Physiological Valuation of Work in the Nykroppa Iron Works Ergonomics Society Symposium on Fatigue [W. H. Floyd and A. T. Welford, editors]. London: Lewis.

Dema, I. S. (1967). 9th A. Conf. Sci. Ass. Nigeria, University of Lagos.

Dieng, K., Lemonnier, D., Bleiberg, F. \& Brun, T. (1980). Nutr. Rep. int. 21, 183.

Durnin, J. V. G. A. \& Passmore, R. (1967). Energy, Work and Leisure. London: Heinemann.

FAO/WHO. (1973). Tech. Rep. Ser. W.H.O. no. 522.

Fox, R. H. (1953). Energy Expenditure of Africans engaged in various rural activities. PhD Thesis, University of London.

Hunter, J. M. (1967). Inst. Br. Georgr. Trans. Papers 41, 167.

Inter-departmental Committee on Nutrition for National Development. (1963). Manual for Nutrition Surveys. Washington, DC: US Government Printing Office.

Jelliffe, D. B. (1969). Monograph Ser. W.H.O. no. 53.

Longhurst, R. \& Payne, P. (1979). Seasonal Aspects of Nutrition. Review of Evidence and Policy Implications. Discussion Paper. Brighton, Sussex: Inst. Dev. Studies.

Phillips, P. G. (1954). J. trop. Med. 57, 12. 